\title{
The ethical issues in the clinical application of stem cells
}

\author{
Fa-guang Huang ${ }^{1}$, Jian $\mathrm{Hu}^{2}$, Jia-fu Liu ${ }^{3}$, Jian - Ping Gong ${ }^{3}$, Yong-Liu ${ }^{3 *}$
}

\begin{abstract}
${ }^{1}$ Department of Surgery, Wuxi County People 's Hospital, No. 100, Wan Tong Road, Wuxi County, Chongqing, China

${ }^{2}$ Department of Hepatobiliary Surgery, The Second Affiliated Hospital of Chongqing Medical University, Chongqing, China

${ }^{3}$ Department of Hepatobiliary Surgery, People's Hospital of Hechuan District, Chongqing Municipality, Hechuan

District Yingpan Street No. 172, China
\end{abstract}

Received: 14 December 2016

Accepted: 16 January 2017

*Correspondence:

Dr. Yong-Liu,

E-mail: 260426944@qq.com

Copyright: (c) the author(s), publisher and licensee Medip Academy. This is an open-access article distributed under the terms of the Creative Commons Attribution Non-Commercial License, which permits unrestricted non-commercial use, distribution, and reproduction in any medium, provided the original work is properly cited.

\begin{abstract}
The current scientific research directing at the stem cells is being a new research hotspot of life science in the $21 \mathrm{st}$ century due to its advantages in clinical treatment. While the clinical application of stem cells brings new hope to the patients, it also brings a lot of medical ethics issues. Therefore, it is necessary that making reasonable efforts on the clinical application of stem cells to meet the requirement of normalization and standardization. This paper covers the clinical application of stem cells and the its ethical problems.
\end{abstract}

Keywords: Clinical application, Ethics, Stem cell

\section{INTRODUCTION}

In 1998, the human embryonic stem cell lines were successfully set up by Shamblott and Thomson. ${ }^{1,2}$ It brought a biological medical revolution which made the basic and clinical application of stem cells become the most popular topic of the $21^{\text {st }}$ century life Science. Thus it has been named one of the biggest scientific and technological achievements both in 1999 and 2000 by the United States magazine "Science".

\section{BASIC CONCEPTS}

Stem cells (SC) are a kind of primitive cells which have some abilities, including infinite proliferation, renewing itself and multiplex differentiation potential. ${ }^{3}$ Under certain conditions, they have the potential of regenerating all kinds of tissue organ and human body, also known as "universal cells". According to different development stages, they can be classified into the embryonic stem cells (ES cells) and adult stem cells (somatic stem cells).
There are four sources for the current human embryonic stem cells, which are: excess gametes or blastocysts from in vitro fertilization, fetal cells from the embryo in Natural or voluntary abortion, blastosphere or single sex split blastocysts from somatic cell nuclear transfer technique, reproductive cells from voluntary donations. ${ }^{4}$

\section{THE CLINICAL APPLICATIONS OF STEM CELLS}

In recent years, with the rapid development of cell biology especially stem cells research, a great deal of explorations has been done in the global stem cell therapy field, which has made a series of exciting results. With some basic research achievements in stem cell therapies such as the blood system, cardiovascular system, diabetes, liver damage, nervous system, retina disease and cancer, its show abroad application prospect. ${ }^{5,12}$

The ethics problems encountered in the clinical application of stem cells. According to the development 
stage, stem cells are divided into embryonic stem cells (ES cells) and adult stem cells (somatic stem cells). Due to a great number of embryonic experiments involved in embryonic stem cells researches, the ethical debate in ES cells field is much more heated compared with adult stem cells, which mainly come from patients themselves. This article mainly introduces the ethical problems of embryonic stem cells.

\section{The debate on the ethical status of human embryo}

The heart of the debate focuses on whether embryo is a human, and whether getting embryonic stem cells is murdering. ${ }^{13}$ To answer these questions, we need to distinguish the biological significance between human being and personality in the sense of people. As a "person", there should have three levels of significance at least. ${ }^{14-16}$

\section{The significance on biology levels}

As a "person", he has the unique genetic materials, which are specific to the people of hominid, personal characteristics with its 23 chromosomes and the related genes, special physical form and function, the development potential of consciousness with experience, and the brain development and social interaction potential.

\section{The significance on psychology levels}

As a "person", he must have self-awareness, or the ability of the conscious experience. Only "person" has selfawareness and the ability of the conscious experience.

\section{The significance on sociology levels}

At any time and any place, a "person" is always in a given society. Conscious experience ability completely formats between people in the social life, which also can format between people in the sense of biology and social interactions. And this character is an essential feature that makes people become a "person".

Xuetao $\mathrm{P}$, the chief scientist and expert group leader of Chinese national 863 plan "tissue organ engineering" major projects, thinks that human embryos has physiological attributes but not social attributes. So the earliest fertilized eggs shouldn't be thought to be person, it is just the beginning of life. So getting embryonic stem cells is not "murder". How should be people? Zong RQ, a famous life ethicist, has argued that according to the confucian view, a man should have shape, mind and consciousness, especially to have self-consciousness. ${ }^{16}$

Additionally, a man also should have the interpersonal ability, but the embryo or fetus in the womb does not have this ability. So an early embryo, without the brain and nervous system, and perceptions is still in the general biological cells, which cannot be said to be a normal person. Therefore, there is no fundamental ethical issue.

\section{The debate on the ethics of humancloning embryos}

At present, the cloning is divided into therapeutic cloning and reproductive cloning by the scientific community. ${ }^{17}$ Therapeutic cloning refers to the organization or the cloned organs for the treatment of diseases. The cloning of embryos manufacturing process used in the laboratory for medical purposes is called the "therapeutic cloning". Reproductive cloning (known as "clone") is a process that human embryos are made based on reproductive cloning technology in the laboratory for the reproductive purpose, which are put human embryos into the body of a woman and then develop into the uterus fetus or babies.

\section{The ethical evidence against reproductive cloning}

\section{Cloning is a challenge for human rights and dignity}

Human cloningis a kind of people made by artificial asexual reproductive cloning technology, whose genetic characters are the same with prototypes being, but the psychological, acquired behavior, social features and particular personality can't be cloned. ${ }^{18}$ So human cloning is a loss of itself and not a complete one, which is a violation of people's unique genetic type rights. Claiming human cloning makes people as reification and tools, which is a serious violation of human rights and human dignity. ${ }^{19-21}$

Cloning is a violation of biological evolution of the natural law of development

The origin of human beings is a great leap of the development of the nature evolution. According to molecular anthropology researches, it has been more than 400 years since man and ape-man began to differentiation. It's the result of sexual reproduction evolution and the social culture of human wisdom development. Therefore, the development of cloning technology, if not properly guided, can also bring calamity to human beings.

\section{Human cloning would disrupt the normal ethical orientation of social family}

The emergence of human cloning will completely disturb the generational relation and family ethical orientation, because in this process can appear three biological parents including donor eggs, somatic cell nuclear donor and bearer. This means that human beings can continue to reproductive breeding on the conditions that there are women and they can provide mature eggs and uterus. Thus, men are no longer necessary in the human reproductive reproduction, which hit the traditional sexual ethics and disrupt the close human relationship between sex and birth. 
The safety of human cloning is difficult to confirm in ethics

The cell level is involved in somatic cell nuclear transfer operation of cloning technology, the risk of losing genetic material in nuclear is obviously far higher than fertilization in vitro. British scientists experienced 227 failures to get a "Dolly". The security of higher cloned mammal has not been solved which has been certificated by the death of dolly.

\section{The ethical evidence supporting therapeutic cloning}

It is reported that although reproductive cloning and sex therapeutic cloning are the same in technology, but the latter plays a major role in human life practice, particular in medical practice. $^{22}$ It has solved many difficult problems in medical practice and will become a revolutionary technology. Therapeutic cloning technology improves the quality of human life, protects human health of body and mind and promotes medical science and technology progress. It brings new hope for human against diseases, and makes personalized treatment become more feasible. From the standpoint of life ethics, therapeutic cloning technology has positive ethical value for treating diseases, it is not only advantageous to contemporary people's health, but also the development of future generations. It not only accords with contemporary people's interests, but also the interests of the future generations. For a long time, human have been exploring various transplant technologies (including heterogeneous allograft, allograft).

The most difficult problems for the development of the transplantation technology are few sources for organs, large exclusive reactions and short survival time. Therapeutic cloning has solved these problems very well in the clinical application. If a patient needs transplant, doctors take clone cells from the patient which can form blastosphere, and then extract stem cells from the blastosphere. Thus, the exactly same cells, tissues or organs to patients' in genetic and characteristics are produced. In theory, the cloned cells come from the patient himself, and share the same genetic characteristics, so these transplantation treatment cells won't produce allograft rejection. Additionally, the stem cells can reproduce infinitely in vitro which means that thousands of patients are waiting for transplants cannot worry about the shortage of the donors.

\section{Unconfirmed ethical problems of stem cell therapy}

The International Society for Stem Cell Research (ISSCR) points out that, in recent years many hospitals and clinics have claimed that they can provide the patients with severe new and effective stem cell therapy, causing many patients suffering from serious illness or injury across borders to find the stem cells "therapy" or "cure" disease methods. ${ }^{23}$ The forming "stem cells tourisms" harm the interests of patients, and even delay the illness, endanger patients' life and cause the attention of all walks of life.

At present the clinical treatment of stem cells still have many disputes. Stem cell technology is still in the test phase, and its clinical effect and safety haven't got international recognized. Hyun I, an associate professor of medical school in Ohio University has pointed out that according to recent studies, some diagnosis sociology institutions exaggerated the benefits of stem cell therapy, and understated the risks of stem cell therapy. ${ }^{24}$ Some medical institutions cannot provide patients with previous results. Whether for economic benefits or profits, or for the good try to help patients, if patients are diagnosed and treated by the standards of some medical institutions, they might be harmed in body and economic. For example, as reported by an Israeli doctor, a young patient suffered from tumors in the brain and spinal cord after a series of embryonic stem cell transplantation in Moscow hospital. The current international management for stem cell therapy is relatively loose, it will produce serious damage in the field of public trust if occurring aforementioned serious consequences.

\section{CONCLUSION}

Human stem cell research and application is a bright career in the history of human civilization, we should support the actively research of our scientists. To ensure the research work smoothly, we ought to establish a series of ethical standards according with the international ethical principles and embryonic stem cell research and application of Chinese national conditions. Under the guidance of the ethics committee, it is a guarantee of properly dealing with the problems of embryonic stem cell researches and applications encountered in ethical, legal and social.

\section{ACKNOWLEDGEMENTS}

Author would like to thank the Second Affiliated Hospital of Chongqing Medical University for their support.

Funding: Chongqing Municipal Health Bureau Fund Conflict of interest: None declared

Ethical approval: Not required

\section{REFERENCES}

1. Shamblott MJ, Axelman J, Wang S, Bugg EM, Littlefield JW, Donovan PJ, et al. Derivation of pluripotent stem cells from cultured human primordial germ cells. Proc Natl Acad Sci. 1998;95:13726-31.

2. Thomson JA, Eldor IJ, Shapiro SS, Waknitz MA, Swiergiel JJ, Marshall VS, et al. Embryonic stem cell lines derived from human blastocysts. Science. 1998;282:1145-7. 
3. The ethics committee of Chinese National Human Genome Center. Ethical Principle of Human Embryonic Stem Cell Research. Medicine and Philosophy. 2003;24(2):19-21.

4. China's ministry of science and technology, and ministry of health. Guidelines for Research on Human Embryonic Stem Cells. Chinese J Reproductive Health. 2004;15(2):71.

5. Yong KW, Choi JR, Wan SWK. Biobanking of human mesenchymal stem cells: future strategy to facilitate clinical applications. Adv Exp Med Biol. 2016;951:99-110.

6. Franco S, Szczesna K, Iliou MS, Qahtani M, Mobasheri A, Kobolák J, et al. In-vitro models of cancer stem cells and clinical applications. BMC Cancer. 2016;16(2):738.

7. Wilson G, Hebbard L, Duan W, George J, Qiao L. Induced pluripotent stem cells (iPSCs) in the gastroenterology and hepatology: from basic research to clinical applications. Curr Stem Cell Res Ther. 2015;10(3):190-2.

8. Wu J, Sun Y, Block TJ, Marinkovic M, Zhang ZL, Chen $\mathrm{R}$, et al. Umbilical cord blood-derived nonhematopoietic stem cells retrieved and expanded on bone marrow-derived extracellular matrix display pluripotent characteristics. Stem Cell Res Ther. 2016;7(1):176

9. Wang M, Yang X, Zhang P, Cai L, Yang X, Chen $Y$, et al. Sustained delivery growth factors with polyethyleneimine-modified nanoparticles promote embryonicstem cells differentiation and liver regeneration. Adv Sci. 2016;3(8):1500393.

10. Bayer EA, Fedorchak MV, Little SR. The influence of platelet-derived growth factor and bone morphogenetic protein presentation on tubule organization by human umbilical vascular endothelial cells and human mesenchymal stem cells in coculture. Tissue Eng. 2016;22(21):1296304.

11. Parfitt DA, Lane A, Ramsden C, Jovanovic K, Coffey PJ, Hardcastle AJ, et al. Using induced pluripotent stem cells to understand retinal ciliopathy disease mechanisms and develop therapies. Biochem Soc Trans. 2016;44(5):1245-51.

12. Borisov MA, Petrakova OS, Gvazava IG, Kalistratova EN, Vasiliev AV. Stem cells in the treatment of insulin-dependent diabetes mellitus. Acta Naturae. 2016;8(3):31-43.
13. Mizuno H. Ethical issues for clinical studies that use human embryonic stem cells: the 2014 revisions to the japanese guidelines. Stem Cell Rev. 2015;11(5):676-80.

14. Monahan P. Developmental biology. human embryo research confronts ethical 'rule'. Science. 2016;352(6286):640.

15. Zhai $\mathrm{X}, \mathrm{Ng} \mathrm{V}$, Lie R. No ethical divide between China and the West in human embryo research. Dev World Bioeth. 2016;16(2):116-20.

16. Qiu RZ, Zhai X. On the ethical supervision and control of stem cell research and clinical application. Chinese Medical Ethics. 2009;22(5):39.

17. Atala A. Tissue engineering of reproductive tissues and organs. Fertil Steril. 2012;98(1):21-9.

18. Shapshay S. Procreative liberty, enhancement and commodification in the human cloning debate. Health Care Anal. 2012;20(4):356-66.

19. Maurice R. Social policy group key ethical issues in embryonic stem cell research. Information Research Services. 2002;5:34-7.

20. Guidelines for the clinical translation of stem cells. ISSCR, Available at www.isscr.org. Accessed on 3 December 2008.

21. Yu LM, Wei W. Ethical scan on technology of clone. Journal Chongqing Jiaotong University. 2007;7(2):53-5.

22. Marks NJ. Speech acts and performances of scientific citizenship: Examining how scientists talk about therapeutic cloning. Public Underst Sci. 2014;23(5):494-510.

23. International society for stem cell research. Guidelines for the clinical translation of stem cells. Available at http:// www.isscr.org /docs/ guidelines/ isscrglclinicaltrans. pdf. Accessed on 3 December 2008.

24. Hyun I. Allowing innovative stem cell-based therapies outside of clinical trials: ethical and policy challenges. Journal Law, Med Ethics. 2010;38(2):277-85.

Cite this article as: Huang FG, Hu J, Liu JF, Gong JP, Liu Y. The ethical issues in the clinical application of stem cells. Int Surg J 2017;4:852-5. 